\title{
Colorful, cute, attractive and carcinogenic: The dangers of dyes
}

\author{
Durinézio José de Almeida ${ }^{1,}$ *, Gabriela Datsch Bennemann², Camila Cristina Bianchi \\ Guilherme Barroso L. de Freitas ${ }^{4,5}$ \\ ${ }^{1}$ Department of Biology, Post-graduate Program in Comparative Biology, State University of Maringa (UEM), Maringá, Brazil \\ ${ }^{2}$ Department of Agronomy, State University of Midwest (UNICENTRO), Guarapuava, Brazil \\ ${ }^{3}$ Department of Nutrition, Faculdade Campo real, Guarapuava, Brazil \\ ${ }^{4}$ Department of Pharmacy, State University of Midwest (UNICENTRO), Guarapuava, Brazil \\ ${ }^{5}$ Department of Clinical Patology, Post-Degree Program in Internal Medicine and Health Sciences, Federal University of Parana (UFPR), \\ Curitiba, Brazil
}

\section{Email address:}

durinezio@gmail.com (D. J. de Almeida), prof.gbarroso@yahoo.com.br (G. B. L. de Freitas)

\section{To cite this article:}

Durinézio José de Almeida, Gabriela Datsch Bennemann, Camila Cristina Bianchi, Guilherme Barroso L. de Freitas. Colorful, Cute, Attractive and Carcinogenic: The Dangers of Dyes. Cancer Research Journal. Vol. 2, No. 6-1, 2014, pp. 42-48. doi: 10.11648/j.crj.s.2014020601.15

\begin{abstract}
Azo dyes and their derivatives have been linked to cases of bladder, prostate, esophagus, rectum, stomach and ovary cancer. These dyes are quite common on food, however, several countries have revised its use and reassessed what are the acceptable concentrations of these pigments. Twilight Yellow and Tartrazine are two azo dyes allowed on food in many countries around the world, they are used for the preparation of gelatins, cake, juices, ready soft drinks, candies, chewing gum, snacks, crackers and etc. Among children and adolescents, the consumption of these foods is common, which can lead to high dye levels in the body. This study examined the concentration of Twilight Yellow and Tartrazine dyes in food consumed by children in Brazilian schools. The results indicated that high consumption of sweets tends to exceed the acceptable daily intake of dyes. Moreover, many products have levels above the allowed by the Brazilian legislation, which increases the risk of cancer.
\end{abstract}

Keywords: Azo Dyes, Twilight Yellow, Tartrazine, Cancer

\section{Introduction}

A series of epidemiological studies about the carcinogenicity of azo dyes and their derivatives have been carried out since the 1979 when these dyes have been linked to bladder cancer in Shanghai workers [1]. Currently these dyes are related to cases of bladder, prostate, esophagus, rectum, stomach and ovarian cancers mainly by the formation of active metabolites (aromatic amines) after the action of intestinal microflora.

The Tartrazine Yellow dye, also known as E102, may be used alone or in combination with the E133 (Brilliant Blue) or E142 (Green S) dyes. In the food industry, although this colorant is widely used in many foods especially those targeted at children (biscuits and sweets, for example) a greater control is still necessary [2].

Studies show that ingestion of artificial pigments such as Tartrazine and Erythrosin associated with a rich diet in trans fats, nitrites, nitrates and low fiber intake are related to malignant neoplasms especially in the esophagus, breast, rectum, stomach and ovary [3]. Other harmful effects observed are allergic reactions, which can generate simple allergies up to severe asthma and bronchitis [4]. Furthermore, the scientific literature attests that $13 \%$ to $22 \%$ of people with allergies to aspirin also exhibit the same reactions after eating the E102 [5].

The intake recommendations of these dyes in food are particular to each country. The reference of consumption used in Brazil is based on scientific studies and other countries legislation. The Brazilian National Health Surveillance Agency (ANVISA) [6] determined that the drug description leaflet of medicines, which contain E102, should have a warning for consumers. However, for food ANVISA requires only the introduction in the list of ingredients, without any warning [3]. This somewhat underestimates the harmful effects of dyes. 
According to the Joint FAO / WHO Expert Committee on Food Additives [7] the acceptable daily intake (ADI) of E102 is $7.5 \mathrm{mg}$ per kilogram per day. This value is used as reference value in Brazil. This means, for example, that a child who weighs $30 \mathrm{~kg}$ should consume at most $225 \mathrm{mg}$ daily to avoid toxic symptoms [8].

The artificial coloring Twilight Yellow, also known as Sunset Yellow FCF or E110, belongs to the group of azo-compound $[9,10]$. It is widely used in fermented foods, soft drinks, jams, juices, fruit cream, jellies, mixes for sauces, snacks, energy drinks, some medications and most processed foods yellowish, reddish or mixtures of other dyes [11]. E110 is often used together with E123 (Amaranth) to yield a chocolate brown and caramels colorations [11]. This dye is a sulphonated Sudan I dye analog, which has carcinogenic potential, and is often present as an impurity in food colored with E123 [12].

Because of many reports of side effects, several studies claim that the azo dyes should be banned from foods [13]. In September 2008, the European Union ruled that the foods and beverages that have any of the artificial azo dyes must contain warnings [8], however, the domestic laws of Norway and Finland have banned the use of E110 in food [13].

In 2009, the European Food Safety Authority (EFSA) [14] has changed the acceptable daily intake (ADI) for E110 of 2.5 to $1.0 \mathrm{mg} / \mathrm{kg}$ body weight per day. Due to the production of carcinogenic aromatic amines and the major toxic effects caused by acute dye exposure at concentration of $100 \mathrm{mg} / \mathrm{kg}$ it was necessary to reduce the ADI to increase the safety [15]. This same concern led to the reduction of the maximum permitted concentration in beverages of $50 \mathrm{mg} / \mathrm{L}$ to $20 \mathrm{mg} / \mathrm{L}$ [8]. According to JECFA, the ADI to Sunset Yellow dye in Brazil is $2.5 \mathrm{mg} / \mathrm{kg}$ body weight, concentration more than double the recommended by EFSA [13].

However, as in some countries e.g. Brazil, it is not necessary to discriminate the amount of these dyes in foods and drinks, only its presence among the ingredients, the supervision and control of possible poisoning or irregularities become difficult $[16,17]$.

The aim of this study was to evaluate the amount of azo dye commonly ingested in the diet of students (children and adolescents) aimed at creating greater control and information, avoiding possible conditions of poisoning and reducing the risk of cancer.

This study was approved by the research ethics committee of the Midwestern State University (UNICENTRO)

\section{Methodology}

This study was undertaken from September 2012 to May of 2013, in order to assess the daily intake of azo dyes. It was carried out a questionnaire with children and adolescents (ages from 4 to 12 years old) of both genders in a public school in Candói, Brazil. This questionnaire was a support for choosing which foods would be quantitatively evaluated for the presence of azo dyes (E102 and E110).

\subsection{Assessment of Dietary Intake of Foods with E102 and E110 Dyes}

There are many foods containing E102 and E110 dyes in its normal composition. In order to analyze which among these foods was the most commonly consumed by students, two tools were used, i.e. one 24-hour recall and a Food Frequency Questionnaire - FFQ [18]. In addition to these potential harmful foods to health, fruits and vegetables were also listed in the questionnaire to check if there was a balance between the consumption of processed and healthy foods. This nutritional equilibrium is essential to assess the risk of onset and progression of tumor cells.

\subsection{Side Effects Related to Food}

Some symptoms caused by azo dyes intoxication are characteristic, for example, vomiting, nausea, diarrhea, swelling of the mouth, itching, headaches and difficulty to breathe. Aiming to identify and quantify the symptoms after ingestion of the foods, the parents filled out a questionnaire reporting the side effects or even if the child has some allergy to any analyzed food.

\subsection{Quantification of Azo Dyes}

Patterns of E102 and E110 dye were used to establish the absorbance curve (Figure 1). The calibration curve was carried out with reference interval of $0.005-0.40 \mathrm{~g} / \mathrm{L}$ (interval of $0.005 \mathrm{~g} / \mathrm{l}$ ) using a spectrophotometer SP - 22 model in wavelength of $450 \mathrm{~nm}$ [19].

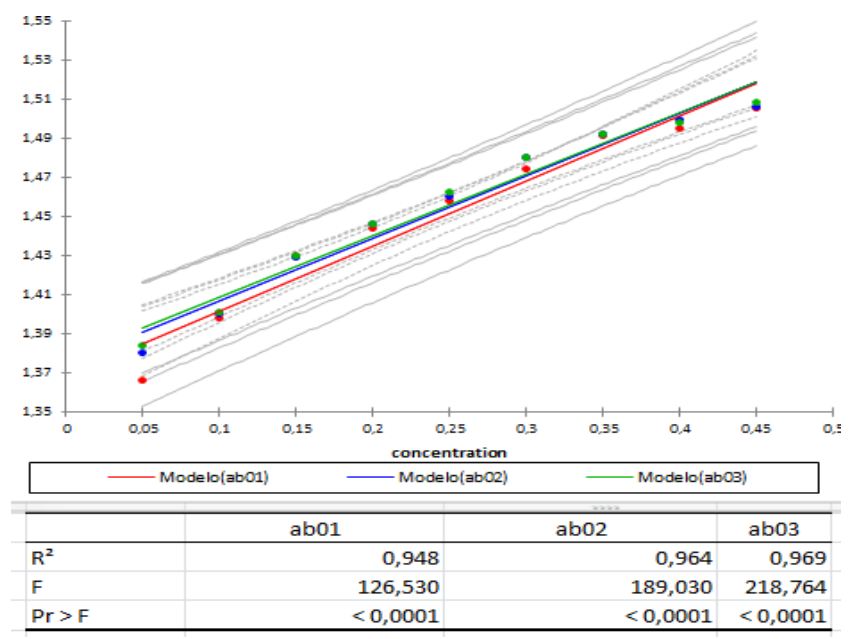

Figure 1. Spectrophotometric curves obtained for the exactness analyzes and its respective tendency curves, being it linear for the Yellow Tartrazine dye. Different colors represent distinct repetitions for the establishment of the curve.

The accuracy of the curves was evaluated in triplicate through the recovery test. The results showed a linear regression $\left(\mathrm{R}^{2}\right)$, varying from 0.94 - 0.96 with a confidence interval of 0.0001 and a standard deviation of 0.044 . The curves established presented an average reliability above $95 \%$, with mean prediction residue of 0.005 .

After reviewing the questionnaire, it became possible to 
select which foods should be included in this study (Table 1). The products were prepared according to the method of preparation of packaging, and then were analyzed one by one in triplicate, being evaluated the amount of dyes according to the methodology described by Santos [19]. In order to increase the reliability of the tests, at least three different brands were selected.

Table 1. Selected foods through of the questionnaires.

\begin{tabular}{ll}
\hline Products & Number of different trademarks \\
\hline Ready juices & 5 \\
Soft drink & 5 \\
Isoelectronic & 3 \\
Popsicle & 5 \\
Powdered soft drink & 9 \\
Gelatin & 5 \\
Puddings & 5 \\
Snacks & 5 \\
Candies & 5 \\
Lollipops & 5 \\
Gums & 5 \\
\hline
\end{tabular}

\subsection{Anthropometrical Evaluation}

The weight was measured following the guidelines of the World Health Organization, using a scale with maximum capacity of $150 \mathrm{~kg}$ and a sensitivity of $0.1 \mathrm{~kg}$ [20]. Two measurements were made through the calculation of the arithmetic mean between them. The classification of the nutritional status was performed according to the indicator of body mass index for age (BMI/A) [20, 21]. The obtaining of the anthropometric assessment enabled to classify them by categories, i. e., thinness, normal weight, risk of overweight and obesity.

\subsection{Statistical Analysis}

The spectrophotometric curves were analyzed in XLSTAT 2012.6.02 for linear regression, with 95\% of confidence interval and a Tolerance equal to 0.0001 . It was performed goodness of fit test for all variables and these were subjected to analysis of variance.

\section{Results}

A total of 79 students with average age of $7.8 \pm 2.1$ participated for the research analysis, among them $55.6 \%$ (n $=44)$ were girls and $44.3 \%(n=35)$ boys.

Through the analysis of the completed questionnaires, one 24-hour recall and Food Frequency Questionnaire, it was observed that artificial juices, chewing gum and the "geladinho" are the foods consumed by most of the students, $75.9 \%, 44.3 \%$ and $68.3 \%$, respectively. It is ascertained that the frequency of daily intake of fruits was of $39.2 \% \quad(n=31)$ and $34.1 \%(n=27)$ weekly, vegetables were of $25.3 \%(n=20)$ daily and $49.3 \% \quad(n=39)$ weekly. The World Health Organization (WHO) published a report considering the importance of alimentation in the prevention of chronic diseases [21], in this report, they state that the insufficient consumption of fruits, legumes and vegetables are found amongst the ten major risk factors for diseases worldwide. According to the organization, approximately 2.7 million deaths can be attributed to the low intake of fruits and vegetables. OMS defines as adequate a minimum intake of 400 grams per day of these foods (equivalent to five daily portions). It can be noted that the students who consume fruits and vegetables do not reach $50 \%$ of the evaluated. During the adolescence the eating habits are being acquired and consolidated, the ones adopted in this period of life have a great influence on the growth and development, negatively reflecting on the individuals' health, $50 \%$ of the students analyzed present eating habits that increase the risk of diseases.

In India, a study conducted by Rao and collaborators [22] demonstrated that between children and adolescents, the average ingestion of industrialized foods with dyes was of $17.2 \mathrm{mg} /$ day/person. The same authors report that in the USA this mean achieves indexes of average consume around 77.1 mg/day/person. The Husaine and collaborators' research [23] describes that four out of nine dyes allowed in Kuwait exceed the IDA for children between two to eight years. Such fact is highly relevant, mainly for the infant health, once the IDA is the measure related to the corporal mass, in which the dyes are source of increase in mutagenicity. Elhkime and his collaborators [24] performed a systematic revision in France with the objective of assessing a safe level of intake of the Tartrazine dye, their results showed that the theoretical maximum intake of Tartrazine must be of $14.5 \%$ for children and $32.2 \%$ for adults, although there is no global parameter, because each country deals with the subject individually, the French parameter can be used as level of comparison until it is established a global index, it is noteworthy that even if it is set a safety index, in the intake case, the physiological individuality still must be observed. In the research performed by Sasaki and his collaborators [25], an experimental study with Wistar mice, was made an analysis of the damage in DNA caused from the intake of additives (dyes and conservators), the researchers concluded that from the concentration of $10 \mathrm{mg} / \mathrm{kg}$ was observed damage in the DNA of the stomach cells, this represents a percentage of $10 \%$ for the IDA of the animal, well below the established in the research in France.

In our study we based on the data obtained from the questionnaires distributed to the students, it was possible to develop a hypothetical menu (Table 2) composed by the food products with greater frequency of intake which contain azo dyes and its comparisons with the IDA.

According to the Brazilian legislation, the limit for an acceptable daily intake of dyes, for children with an average weight of $28 \mathrm{Kg}$, is of $210 \mathrm{mg} /$ day for the Tartrazine and $70 \mathrm{mg} /$ day for the Twilight. The eighth column presented in Table 5 shows the results which exceed the values allowed by the legislation. Two distinct studies [26], also reported that the overconsumption of foods with dyes is an increasingly common practice during the childhood, being that it tends to continue over the years. Nogueira and collaborators [27] observed excessive intake of soda pop on the mean age of 
9.2 \pm 2.4 years for girls and 11.4 \pm 2.4 for boys. Our data revealed an overconsumption of dyes in many foods, among these there are the soft drinks and industrialized juices. This consumption of beverages combined to the substitution of water intake can result in physiological effects related to the conversion of azo dyes into aromatic amines, which can have direct relation with the prevalence of bladder cancer. Moreover, these drinks present high quantity of sugar, elevating the risk of diabetes and resistance to insulin, risk factors for several types of cancer.

Another aspect for taking into consideration is the possible variation in the concentration of dyes described on the label (when described) and the real concentration in the product, which would worsen the already existing situation of overconsumption.

Table 2. Frequency of foods with dyes and Hypothetical Menu in a school which tends towards sweets, with the analyzed student presenting a body weight of $28 \mathrm{~kg}$, according to the 50th percentile (WHO, 2006). Reference values according to the legislation. Maximum dose (mg of dye to students with approximately $28 \mathrm{~kg}$ ).

\begin{tabular}{|c|c|c|c|c|c|c|c|}
\hline Product & $\begin{array}{l}\text { consume } \\
\text { diary }\end{array}$ & Dyes & $\begin{array}{l}\text { Acceptable } \\
\text { Daily Intake }\end{array}$ & $\begin{array}{l}\text { Maximum } \\
\text { dose }\end{array}$ & $\begin{array}{l}\text { Ceiling in } 100 \mathrm{~g} \\
\text { of product }\end{array}$ & $\begin{array}{l}\text { Total consumed } \\
\text { dye }\end{array}$ & $\begin{array}{l}\text { \% Excessive dye intake } \\
\text { compared to the IDA }\end{array}$ \\
\hline \multirow[t]{2}{*}{ Refreshment } & \multirow[t]{2}{*}{$300 \mathrm{ml}$} & E110 & 2.5 & 70 & 10 & 30 & 42.9 \\
\hline & & E102 & 7.5 & 210 & 10 & 30 & 14.3 \\
\hline \multirow[t]{2}{*}{ Gelatin } & \multirow[t]{2}{*}{$100 \mathrm{~g}$} & E110 & 2.5 & 70 & 10 & 10 & 14.3 \\
\hline & & E102 & 7.5 & 210 & 15 & 15 & 7.1 \\
\hline \multirow[t]{2}{*}{$\begin{array}{l}\text { Chewable } \\
\text { sweets }\end{array}$} & \multirow[t]{2}{*}{$30 \mathrm{~g}$} & E110 & 2.5 & 70 & 10 & 3 & 4.3 \\
\hline & & E102 & 7.5 & 210 & 30 & 9 & 4.3 \\
\hline \multirow[t]{2}{*}{ Fried chips } & \multirow[t]{2}{*}{$60 \mathrm{~g}$} & E110 & 2.5 & 70 & 10 & 6 & 5.1 \\
\hline & & E102 & 7.5 & 210 & 10 & 18 & 1.7 \\
\hline \multirow[t]{2}{*}{ Ice Cream } & \multirow[t]{2}{*}{$100 \mathrm{~g}$} & E110 & 2.5 & 70 & 10 & 3.6 & 14.3 \\
\hline & & E102 & 7.5 & 210 & 10 & 3.6 & 4.8 \\
\hline \multirow[t]{2}{*}{ "Geladinho" } & \multirow[t]{2}{*}{$300 \mathrm{ml}$} & E110 & 2.5 & 70 & 10 & 10 & 42.9 \\
\hline & & E102 & 7.5 & 210 & 15 & 10 & 21.4 \\
\hline \multirow[t]{2}{*}{ lollipop } & \multirow[t]{2}{*}{ 2un } & $\mathrm{FCF}$ & 2.5 & 70 & 10 & 3 & 4.3 \\
\hline & & E102 & 7.5 & 210 & 15 & 9 & 4.3 \\
\hline
\end{tabular}

In this study, the quantitative analysis of foods verified that most of the studied foods have high levels of azo dyes (values above the allowed by the local legislation) (Figure 2). Side effects due to the excess of azo dyes are reported in several scientific studies, for example, bronchospasm, urticaria, angioedema and hyperkinesia in hyperactive patients. The Twilight yellow dye in special can be the responsible for causing allergic reactions in people with intolerance to aspirins, bringing various symptoms, such as diarrhea, vomiting, urticaria, gastrointestinal problems, swallows on the skin and migraines [12].

In Figure 2 it is possible to observe the mean values of azo dyes between the major brands of liquid food products. Four out of five brands of ready juices which were more consumed by our voluntaries surpassed the reference values for the intake of Twilight Yellow.

For the analysis of soft drinks, it were selected the four main brands consumed by the students, and all of them presented values above the allowed for E102. Also, three out of five of the products considered isotonic were above the described on the label. In the assessment of five brands of "geladinho", all presented an excessive amount of dye, an average around $279.6 \%$ of the value established as maximum for $100 \mathrm{~g}$ of the product. These results emphasize the need of a more present monitoring and correct information on labels.

For the analysis of soft drinks, it were selected the four main brands consumed by the students, and all of them presented values above the allowed for E102. Also, three out of five of the products considered isotonic were above the described on the label. In the assessment of five brands of "geladinho", all presented an excessive amount of dye, an average around $279.6 \%$ of the value established as maximum for $100 \mathrm{~g}$ of the product. These results emphasize the need of a more present monitoring and correct information on labels.

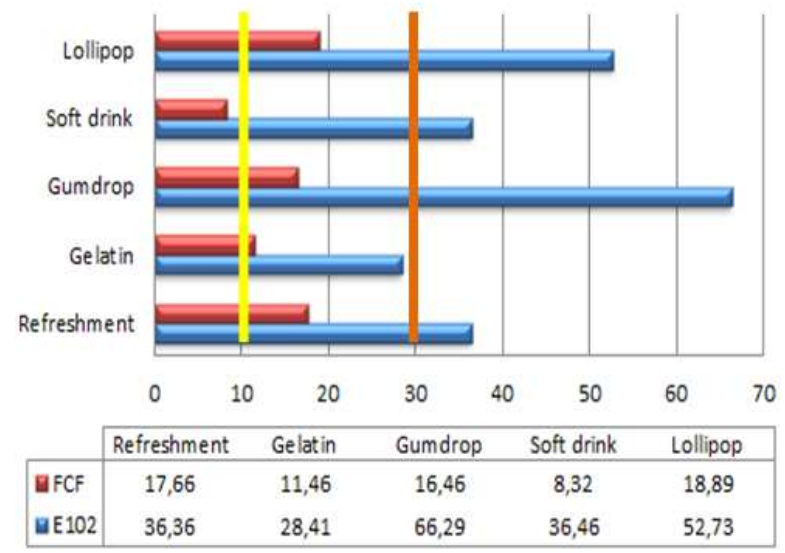

Figure 2. Average quantity of $\mathrm{mg} / 100 \mathrm{~g}$ of Twilight Yellow (FCF) and Tartrazine yellow (E102) found (red and blue bars, respectively) according to the chemical analysis. The yellow column represents the limit of FCF while the orange represents the limit for the E102, according to the Brazilian legislation.

For the analysis of soft drinks, it were selected the four main brands consumed by the students, and all of them presented values above the allowed for E102. Also, three out of five of the products considered isotonic were above the described on the label. In the assessment of five brands of "geladinho", all presented an excessive amount of dye, an average around $279.6 \%$ of the value established as maximum 
for $100 \mathrm{~g}$ of the product. These results emphasize the need of a more present monitoring and correct information on labels.

We also assessed dehydrated artificial juices, gelatins, puddings, seasoning for pasta, snacks, candies and lollipops. Again were found irregularities as for the concentration in each of these products, specifically in candies, where it was found a dye concentration of $45 \%$ above the allowed for the Twilight and $89 \%$ for the Tartrazine.

From the nutritional point of view, the sweets are truly empty calories, i. e. do not add to health any important and adequate nutrient for the nutritional needs of growth and development of the child and the adolescent [28]. Although there is a metabolic difference associated to each individual, the overconsumption of sweets with dye excess increases even more the risk of harmful effects to health. If we add the direct risk of cancer development with the increase of overweight probability, it can be measured a worrying level of factors that can lead to the onset of cancer in the voluntaries.

In the Sorensem and Price [29] study about obesity in Denmark, it can be noted that exists an increasing number of the obesity rate which has been following the centuries, likewise in the US, Dietz and his collaborators [30, 31] observes this increase in children and adolescents in the range between 6 to 14 years old and discusses that obesity is an effect of the relation host environment in which exists a direct correlation between life and food habits and the onset of the disease. Obesity has direct relation with cancer, for altering factors of transcription, cytokines and altered estrogen production [32]. In order to best understand the influence of alimentation on the corporal development of the students, and the possible risks of chronic diseases, an anthropometric assessment was carried out (Table 3).

Table 3. Anthropometric classification of the students according to the curves of the OMS 2006-2007.

\begin{tabular}{llllllll}
\hline \multirow{2}{*}{ Gender } & Thinness & \multicolumn{2}{c}{ Normal weight } & \multicolumn{3}{c}{ Risk of overweight } \\
\cline { 2 - 8 } & $\mathbf{n}$ & $\mathbf{\%}$ & $\mathbf{n}$ & $\boldsymbol{\%}$ & $\mathbf{n}$ & $\mathbf{\%}$ & $\mathbf{\text { Obesity }}$ \\
\hline Masculine & 0 & 0 & 22 & 62.8 & 13 & 37.1 & 0 \\
Feminine & 06 & 13.6 & 28 & 63.3 & 04 & 9.09 & 06 \\
\hline
\end{tabular}

The BMI data revealed prevalence of the eutrophic nutritional status, adequate for the age. However, a worrying number of boys $(37.1 \%)$ and girls $(22.7 \%)$ are found overweighing. Apparently, caloric foods in excess associated to the lack of physical exercises are the main factors responsible for these data, which can be already considered a world situation.

Another constant report about the relation dyes-foods are the allergies. Studies have related allergic problems to other harms to health through the intake of foods which have dyes in their composition [33]. The main consequences of dyes use among children are: allergies, attention deficit disorder, mental retardation, asthma, skin lesions and gastric problems. In our results the main symptoms cited after the ingestion of foods with dyes were diarrhea $44.3 \%$, vomiting $48.1 \%$ itching $29.1 \%$. Allergic reactions are unusual responses of the immunological system and represent reactivity and an altered antigen, usually a xenobiotic [34]. The reactions appear quickly, arising within two hours after the ingestion, varying according to the quantity of the allergen absorbed. It may manifest as abdominal pain, nausea, vomiting, diarrhea, gastrointestinal bleeding, itching in the mouth or throat. It can also appear skin disorders, such as redness, urticaria, cold sores and swelling [35]. The incidence of food allergy is elevated amongst pediatric patients, due to the intake of foods which contain dyes in its composition. It is estimated that these foods reactions occur in $6 \%$ to $8 \%$ of the children under three years old and in $2 \%$ to $3 \%$ of the adults [36]. In Australia, an average of $6 \%$ of the children with less than five years has some kind of food allergy, comparing with $1 \%$ to $2 \%$ of the adults [37].

In the USA, $6 \%$ of the children have food allergy as well as $3 \%$ to $4 \%$ of the adults [38]. According to the Center for Disease Control (CDC) in the USA, between 1999 and 2009 there was an increase of $18 \%$ of food allergies in kids [39]. The manifestation of food hypersensitivity varies ac-cording to the culture and type of population, for example, Hispanic children have low indexes of foods allergies when compared to the Caucasian or non-Hispanic black children [40]. In Portugal, there are no data available about the epidemiology. Nevertheless, a Portuguese study carried out with children followed in the Immunoallergology consulta-tion in the Dona Estefânia Hospital identified a prevalence of $8.5 \%$ of food allergy between the ages of 0 to 18 , being the egg, milk, fish and crustaceans the main allergens [41]. However, further researches about the effects of dyes are still few.

As for the association of intake of azo dyes and adverse effects to health, the pathogenic mechanisms are still insufficiently studied. With this, it is evident the need of greater attention to the effects of these foods, mainly the chronic and sub chronic. Chung [42, 43] reports that the use of dyes is associated to the industrialization degree of the country, the more industrialized a country is, more dyes are being consumed by the population, in highly industrialized countries, there is a high prevalence of intestinal cancer, and the author rises the hypothesis that there may be a possible link between the increase of intestinal cancer and the use of azo dyes. Chung $[42,44]$ also emphasizes that the azo dyes can be reduced to aromatic amines by the intestinal microflora. According to the Brazilian Society of Urology, around $20 \%$ of the bladder cancer cases are associated to the occupational exposure to aromatic amines, which are also present in the smoke of cigarettes and its metabolites excreted in the urine of smokers are responsible for about $50 \%$ of the bladder cancer cases [45]. For Weliky and Heiner [4], a common requisite for the chemically induced allergy and carcinogenesis in the liver is the capacity of the product in reacting to form covalent conjugates, as occurs with the 
aromatic amines, the propensity of an individual to convert normally innocuous chemical products to form reactive forms under the physiological conditions, can proportionate an indicator of risk of developing cancer. Yahagi and collaborators (1975) tested the mutagenicity of azo dyes and its derivates in Salmonella typhimurium (TA100 and TA98. Mix S-9), obtained in a culture enriched with mice liver [47]. Their results suggest that the carcinogenic effects of azo dyes depend that the enzymes present in the liver and the produced sub products promote a modification on the DNA of bacteria. On the other hand, more recent studies state that the acting of the liver enzymes is irrelevant for modification of azo dyes into aromatic amines [48]. Up to this moment, it is believed that the intestinal microflora and a wide variety of anaerobic bacteria are the main responsible for cleaving the azo bond and induce the production of aromatic amines [44].

\section{Conclusion}

The overconsumption of candies and industrialized food by schoolchildren tends to surpass the Acceptable Daily Intake (IDA) for azo dyes. Moreover, many products present contents above the allowed by the Brazilian legislation, which increases the risk of neoplasms in this type of consumer. Through this study it is possible to notice the need of some immediate actions, i. e. greater control by the regulatory agencies, the readjustment of labels indicating the amount of dyes in the food, nutritional education of the students and mainly further studies about the effects of dyes intake in short and long term. Cancers of gastrointestinal tract are directly related to alimentation, so, low ingestion of healthy foods and increase of sweets associated to high concentration of dyes should be considered a problem for the public health.

\section{References}

[1] You X Y, Chen J G., Hu Y N (1990) Studies on the relation between bladder cancer and benzidine or its derived dyes in Shanghai. Br J Ind Med. 47(8), 544-

[2] Souza C F (2000) Aditivos: aplicações e aspectos toxicológicos em produtos de confeitaria, particulamente em glacê e coberturas para bolos. Universidade Federal do Rio Grande do Sul, Porto Alegre, Brasil.

[3] Polônio M L T, Peres F (2009). Consumo de aditivos alimentares e efeitos à saúde: desafios para a saúde pública brasileira. Cad Saúde Pública, 25(8), 1653-66.

[4] Cosentino H M (2005) Efeitos da Radiação Ionizante em Corantes Naturais de Uso Alimentício. 20149p. Thesis Doctorate in Science, Instituto de Pesquisas Energéticas e Nucleares, Autarquia associada à Universidade de São Paulo, São Paulo.

[5] Barufaldi R, Oliveira M N (1999) Fundamentos de tecnologia de alimentos. São Paulo. Editora Atheneu, volume 3, 153-190.

[6] Agência Nacional de Vigilância Sanitária - ANVISA. (2013) http://www.anvisa.gov.br/legis/resol/44_77.htm. Accessed in April 2014.
[7] Report of a Joint FAO/WHO Consultation. World Health Organization (WHO). (2003) Diet, nutrition and the prevention of chronic diseases. Geneva, WHO.

[8] Associação Brasileira de Indústria de Massas - ABIMA. (2007) Considerações sobre o corante Amarelo Tartrazina. Informe Técnico $n^{\circ}$. 30, de 24 de julho de 2007.

[9] Moreira LF (2006) Estudo dos componentes nutricionais e Imunológicos na perda de peso em Camundongos com alergia alimentar. Dissertação Mestrado em Patologia Geral, Universidade Federal de Minas Gerais, Belo Horizonte.

[10] Coultate V R (2004) Alimentos: a química de seus componentes. 3 ed, Ed. Artmed, Porto Alegre, Brasil.

[11] Kapor M A, Yamanaka H, Carneiro P A, Zanoni M V B (2001) Eletroanálise de corantes alimentícios: determinação de índigo carmim e tartrazina. Eclet Quím. 26, 53-68.

[12] Zeng W, Wang P, Zhang H, Tong S (1993) Qualitative and quantitative analyses of synthetic pigments in foods by using the branch and bound algorithm. AnalyticaChimicaAct 284, 445-

[13] Prado M A, Godoy H T (2003) Corantes artificiais em alimentos. Alim Nutr 14 (2), 237-50.

[14] Kleter G A, Prandini A, Filippi L, Marvin H J P (2009) Identification of potentially emerging food safety issues by analysis of reports published by the European Community's Rapid Alert System for Food and Feed (RASFF) during a four-year period. Food Chem Toxicol. 47 (5), 932-50.

[15] Shumann, S P A; Polonio, M L T, Gonçalves, E C B A (2008) Avaliação do consumo de corantes artificiais por lactentes, pré-escolares e escolares. Ciênc Tecnol Aliment. 28 (3), 534-39.

[16] Brasil. (1997) Decreto $\mathrm{n}^{\circ}$ 55871, de 26 de março de 1965 Modifica o Decreto $\mathrm{n}^{\circ}$ 50.040, de 24 de janeiro de 1961, referente a normas reguladoras do emprego de aditivos para alimentos, alterado pelo Decreto $n^{\circ} 691$, de 13 de março de 19Diário Oficial da União, Brasília, DF.

[17] Brasil. (1997) Portaria $\mathrm{n}^{\circ} 540$ - SVS/MS, de 27 out. 19Regulamento técnico: aditivos alimentares - definições, classificação e emprego. Diário Oficial da União, Brasília, DF.

[18] Fisberg R M, Marchioni D M L (2012) Manual de avaliação do consumo alimentar em estudos populacionais: a experiência do inquérito de saúde em São Paulo (ISA) / Universidade de São Paulo. Faculdade de Saúde Pública. 197 p.

[19] Santos, M E, Demiate I M, Nagata N (2010) Simultaneous determination of tartrazine and sunset yellow in food by spectrophotometry UV-VIS and multivariate calibration methodology. Ciênc Tecnol Aliment. 30 (4), 903-9.

[20] World Health Organization (2006) Multicentre Growth Reference Study Group. WHO Child Growth Standards: Length/height-for-age, weight-for-age, weight-for-length, weight-for-height and body mass index-for-age: Methods and development. Geneva: WHO, 312p.

[21] World Health Organization (2007) Multicentre Growth Reference Study Group. Development of a WHO growth reference for school-aged children and adolescents. Bulletin of the World Health Organization. 85, 660-7. 
[22] Rao P, Bhat R V, Sudershan R V (2004) Exposure assessment to synthetic food colors of a selected population in Hyderabad. India. Food Addit Contam. 21 (5), 415-

[23] Husain A S, Bhedts S (2006) Estimates of dietary exposure of children to artificial food colours in Kuwait.Food Addit Contam. 23 (3), 245-51.

[24] Elhkim M O, Héraud F, Bemrah N, Gauchard F, Lorino T, Lambré C, Frémy J M, Poul J M. (2007) New considerations regarding the risk assessment on Tartrazine An update toxicological assessment, intolerance reactions and maximum theoretical daily intake in France. Regul Toxicol Pharmacol. 47 (3), 308-16.

[25] Sasaki Y F, Kawaguchi S, Kamaya A, Ohshita M, Kabasawa K, Iwama K, Taniguchi K, Tsuda S (2002). The comet assay with 8 mouse organs: results with 39 currently used food additives. Mutat Res. 519, 103-19.

[26] Nogueira R S (2004) Consumo de corantes em produtos industrializados por pré-escolares: risco à saúde infantil. Trabalho de Conclusão de Curso. Rio de Janeiro: Universidade Federal do Estado do Rio de Janeiro.

[27] Nogueira F A M, Schieri R (2009) Associação entre consumo de refrigerantes, sucos e leite, com o índice de massa corporal em escolares da rede pública de Niterói, Rio de Janeiro, Brasil. Cader Saúde Pública. 25 (12), 2715-24.

[28] Sorensen T I, Price R A (1990). Secular trends in body mass index among Danish young men. Int J Obes. 14, 231-9.

[29] Dietz W H, Gortmaker S L (1985) Do we fatten our children at the television set? Obesity and television viewingin children and adolescents. Pediatrics 75 (5) 807-12.

[30] Dietz W H, Bandini L G, Gortmaker S (1990) Epidemiologic and metabolic risk factors for childhood obesity. Klin. Padiatr $202(2), 29$

[31] Calle E E, Kaaks R (2004) Overweight, obesity and cancer: epidemiological evidence and proposed mechanisms.Nat Rev Cancer 4 (8), 579-91.

[32] Borzelleca J F, Hallagan . (1988). A chronic toxicity/carcinogenicity study of FD\&CYellow No. 5 (Tartrazine) in mice. Food Chem Toxicol 26 (3), 189-94.

[33] Goodwin P J, Stambolicb V (2011) Obesity and insulin resistance in breast cancer - Chemoprevention strategies with a focus on metformin. Breast 20(3), 31-S35.

[34] Mahan LL, Escott- Stunp S, (2002) Krause alimentos, nutrição \& dietoterapia. ed. São Paulo: Roca, 66-72.
[35] Associação Brasileira de Alergia e Imunologia Copyright disponível em http://www.sbai.org.br/secao.asp?s=81\&id=306

[36] Host A, Halken S, Muraro A, Dreborg S, Niggemann B, Aalberse R, et al. (2008) Dietary prevention of allergic diseases in infants and small children. Pediatr Allergy Immunol 19 (1), 1-4.

[37] Beyer K, Morrow E, Li X M, Bardina L, Bannon G A, Burks A W, Sampson H A (2001) Effects of cooking methods on peanut allergenicity. J Allergy Clin Immunol 107 (6), 1077-81.

[38] Sampson H A, Ho D G. (1997) Relationship between food-specific IgE concentrations and the risk of positive food challenges in children and adolescents. J Allergy Clin Immunol 100 (4), 444-51.

[39] Wegienka G, Joseph C L, Havstad S, Zoratti E, Ownby D, Johnson C C (2012) Sensitization and Allergic Histories differ between Black and White Pregnant Women. Allergy Clin Immunol 130 (3), 657-

[40] Cunha L A S, Pinto A T, Neves F, Barata D, Pereira A C (2012) Health-related quality of life of pediatric intensive care survivors Francisco. J Pediatr 88 (1).

[41] Chung K T (1983) The significance of azo-reduction in the mutagenesis and carcinogenesis of azo dyes. Mutat Res 114 (3), 269-81.

[42] Chung K T, Cerniglia C E (1992) Mutagenicity of azo dyes: structure-activity relationships. Mut Res 277 (3), 201-20.

[43] Chung K T, Stevens S E, Cerniglia C E (1992) The reduction of azo dyes by the intestinal microflora. Crit Rev Microbiol 18 (3), 175-

[44] Pompeo A C L, Carrerette F B, Glina S, OrtizV, Ferreira U, Fonseca E C C, et al. (2008) Câncer de bexiga - diagnóstico Ver Assoc Med Bras 54 (2), 100-1.

[45] Weliky N, Heiner D C (1985) A common route for the lesion tissue, and chemical-induced immune responses leading to hypersensitivity and/or carcinogenesis. Med Hipóteses 16 (1), 69-9.

[46] Yahagi T, Degawa M, SeinoY, MatsushimaT, Nagao M (1975) Mutagenicity of carcinogenic azo dyes and their derivatives .Cancer Lett 1 (2), 91-6.

[47] Martin C N, Kennelly J C (1981) Rat liver microsomal azoreductase activity on four azo dyes derived from benzidine, 3,3'-dimethoxybenzidine or 3,3'-dimethoxybenzidine. Carcinogen 2 (4), 307-12. 